\title{
4 Teaching Talmudic Hermeneutics Using a Semiotic Model of Law
}

\author{
Daniel Reifman
}

A major difficulty students face in mastering Talmud study-beyond developing the requisite textual skills to make sense of the Talmud text ${ }^{1}$ - is acclimating to the Talmud's mode of reasoning. Students' assumptions regarding logic and common sense are stymied by the Talmud's tendency to juxtapose laws from disparate areas of halakha, make strained inferences from earlier sources, and construct hair-splitting distinctions. Such phenomena occur so often as to be unavoidable, and when students come across them they are usually encouraged to "suspend disbelief" as they work through the give-and-take of the debate. Practical though it may be, this approach only postpones addressing the underlying problem: students' frustration with a thought process that seems very foreign to their own.

Essentially, what students of Talmud have difficulty with is thinking about law. Although some of the seemingly illogical aspects of Talmudic reasoning are unique to halakhic discourse, most of the analytical practices described above are-in one form or another-endemic to any highly developed legal system. What is required to help students make sense of the Talmud's mode of thinking, then, is a model of how law functions.

The usefulness of thinking about halakha as a typical legal system is not limited to beginning Talmud students. As students advance to more complex sugyot, a host of questions about the nature of the halakhic system invariably arises: Why do some areas of halakha exhibit greater

1 I would group these skills into three general categories: 1) language: nonHebrew speakers need to master the basics of both mishnaic Hebrew and the Aramaic of the Babylonian Talmud; 2) syntax: the traditional printings of the Talmud do not contain punctuation, so students must learn how to parse the text; 3) terminology: the text of the Bavli is structured primarily by means of a few dozen key terms and phrases, whose literal meanings are less significant than the functions they serve within the text. 
degrees of flexibility than others? What are the functional limits on what a text can be interpreted to mean? How does halakha incorporate data from other disciplines, such as ethics, sociology, and the sciences? These, too, are issues that legal theorists must grapple with in analyzing any legal system, and the approaches they have developed within other legal systems can provide useful models for halakha, as well.

The issue of how law functions is, of course, the subject of a longstanding debate within the field of legal theory. Although the precise positions on each side shift from generation to generation, the basic tension remains between those who perceive law as a system based on a fixed set of principles and those who challenge the coherence of any such system. In recent years, some legal scholars have sought a middle ground, describing the way law functions as a cohesive system despite its fundamental indeterminacy.

This paper will propose that a semiotic model has significant advantages in explaining how law functions, and as such is useful in helping students make sense of many aspects of Talmudic reasoning. This model is based on the premise that law is most fundamentally a system of signs, and follows the same basic rules as other sign systems, such as language. By using the same methodology that semioticians use in analyzing other sign systems to analyze the way legal texts generate meaning, we can give students a framework for making sense of the seemingly illogical aspects of Talmudic reasoning, as well as addressing higher-order questions about the nature of halakhic development.

Obviously many students will not find explicit use of semiotics helpful. However, even if the term "semiotics" is never mentioned in the classroom, many of the basic principles that emerge from a semiotic model of law can be translated into simple didactic techniques that can help in achieving the aforementioned goals. Indeed, the techniques that teachers (and students) find most effective for teaching Talmud and halakha usually reflect these principles, and greater awareness on the part of the teacher of how these principles operate can help her fine-tune her use of these techniques. Moreover, there are some students who are ready for a more sophisticated understanding of how halakha functions as a system, and for whom explicit exposure to semiotic theory within the context of a Talmud or halakha class can be extremely beneficial.

In exploring how this methodology can be used in a classroom setting, this paper will present examples drawn from two of my classes 
during the 2006-7 academic year, when I first began testing this methodology with my students. Most of the texts presented were covered in my class on the third chapter of Kiddushin at Yeshivat Chovevei Torah, geared toward students with 2-3 years of experience studying Talmud. The class's goal was simply to increase the students' facility with the Talmud text and basic commentaries. I have also drawn on texts from one of my classes at the Drisha Institute for Jewish Education, an advanced halakha class on the laws of kashrut. During that year, I also used this approach in a continuing education course at Drisha examining the "Shabbes goy," looking at Jacob Katz's seminal work in the field of history of halakha ${ }^{2}$ from a legal-theory standpoint (as a complement to Katz's historical-critical analysis). Despite the varying skill levels of the students and the different focuses of the courses, I found that a semiotic approach lent itself equally well to all three classes, and students almost uniformly confirmed that it enhanced their understanding of the material. ${ }^{3}$

In the interest of clarity, all the examples I have chosen relate to a single phenomenon in Talmudic hermeneutics - the statutory interpretation of mishnayot. It should become clear, however, that this methodology has implications for a broad range of issues in rabbinic hermeneutics and general philosophy of law.

\section{Developing a Semiotic Model of Law}

In order to clarify what is meant by a semiotic model of law, let us first review how the field of semiotics analyzes other sign-systems, such as language, highlighting several features that will be relevant to our analysis of law. One of the foundational principles of semiotics is Ferdinand de Saussure's tenet that signs are composed of two distinct elements:

2 Jacob Katz, The "Shabbes Goy": A Study in Halakhic Flexibility, trans. Yoel Lerner (Philadelphia: Jewish Publication Society, 1989).

3 A previous version of this chapter, which also explores the texts I used in the continuing education course, appears under the same title as Working Paper No. 17 in the series produced by the Initiative on Bridging Scholarship and Pedagogy in Jewish Studies at the Mandel Center for Studies in Jewish Education at Brandeis University (April 2010). See http://www.brandeis.edu/mandel/ pdfs/Bridging_working_papers/ReifmanPaper_rev51810.pdf 
the signifier or sign-vehicle - the aural or written form of the word-and the signified or sign-meaning-the mental concept it evokes. (For the sake of convenience, I will follow Umberto Eco's use of the notations /X/ to denote the vehicle of sign $\mathrm{X}$ and " $\mathrm{X}$ " to denote its meaning. ${ }^{4}$ ) Although within a given context the signifier and signified function as a unit, like two sides of a piece of paper, it is crucial to Saussure's theory that the two are not inextricably bound, because their distinctness is what allows for polysemy-a given form signifying more than one concept-and synonymy - a given concept being represented by more than one form. For example, the English language pairs the sign-vehicle /plane/ with a number of sign-meanings, among them "aircraft", "level", or "carpentry tool"; conversely, the concept "flying vehicle" can be represented either as /plane/ or /aircraft/. ${ }^{5}$

A corollary of the fact that the signifier and signified are discrete entities is that the relationship between them is arbitrary and therefore completely dependent on context: expression and content enter into mutual correlation under established coded circumstances. An observer who isn't familiar with the code being used (e.g., someone reading or hearing a foreign language) can't attach any meaning to the signifiers she observes because she lacks the necessary context for decoding them. And because a given signifier can encode for multiple meanings even within a given semiotic system, even those familiar with that system can be confounded by ambiguity if the context doesn't rule out all but one meaning. In such circumstances, signs can be disambiguated only by invoking a second signifier, which we will refer to as the interpretant, ${ }^{6}$

4 Umberto Eco, A Theory of Semiotics (Bloomington: Indiana University Press, 1976), xi.

5 Ibid., 49.

6 Ibid., 68-70. The use of the term "interpretant" in this context traces back to the nineteenth-century American semiotician Charles Sanders Peirce, who conceived of a triadic model of semiotics (object-representamen-interpretant), wherein the interpretant is the effect that the representamen (the equivalent of Saussure's "signified") has on the interpreter that allows him to associate the representamen with its object. Peirce added, however, that the interpretant itself then becomes a representamen, which triggers another interpretant, in an endless process of semiosis. The relevance of this last notion for legal semiotics will be evident later in the paper. However, in the interest of simplicity, I have chosen to use the more straightforward terminology of Saussure's binary model. 
whose significance is that it has an overlapping-but not completely identical - semantic range with that of the first signifier: the intersection between the semantic ranges of the first signifier and the interpretant defines which aspects of the first signifier's meaning are relevant in this context. For example, if /plane/ appeared in a context where its meaning was not evident, then /aircraft/ (or /level/ or /carpentry tool/) could serve as the interpretant to clarify what was meant. /Aircraft/ doesn't replace the original signifier, since it can be used to refer to things that couldn't be called /plane/, such as a helicopter; rather, the interpreter would now understand that the semantic range of the original signifier is limited to those objects that can be referred to both as /plane/ and as /aircraft/, that is to say, objects that fall within the semantic ranges of both the original signifier and the interpretant.

The above example is a fairly simple case of disambiguation, since the various possible sign-meanings of /plane/ are mutually exclusive: there is no object that could be referred to both as /aircraft/ and as /carpentry tool/. However, even when the general sign-meaning being referred to is clear, what is often ambiguous is which aspects of that sign-meaning are pertinent. In such cases, it is helpful to think of the sign-meaning as a bundle of semes - isolable units of meaning-only some of which may be relevant in a given context. Consider the following perfectly banal exchange:
A: "Please bring me a chair."
B: "What do you need it for?"
A: "I'd like something to sit on."

In this case, the primary signifier being analyzed is /chair/, and the interpretant that clarifies its meaning is /something to sit on/. When B asks, "What do you need it for?" he is essentially inquiring what part of the semantic range of /chair/ is relevant in this situation. For although the meaning of A's request may seem straightforward, that is only because we subconsciously impose a particular context on the situation, namely that $A$ is standing and would like to sit down. Were A's request made in a cold room with a dying fire, it would be clear that A intended to use the chair as fuel, and the pertinent semes would be ones that relate to the chair's material construction, not its function. In this context, the semantic range of /chair/ might include "table", "broomstick"—mean- 
ings that we ordinarily would never associate with /chair/, because we reflexively translate /chair/ into /something to sit on/.

Moreover, even once it's been established that A wants the chair to sit on, the interpretant /something to sit on/ clarifies only that the general function of the chair is relevant, but doesn't tell us if more specific design features that relate to the chair's function-such as a back or firm seat-are also significant. If a stool or sofa would also fulfill A's request, then it would emerge that these other features are not relevant semes of /chair/ in the context of A's request, and that /something to sit on/, rather than /chair/, is a more precise expression of A's desire.

What this example makes clear is that on one level, semiotics simply creates a framework for precise analytical reasoning: in distinguishing between signifier and signified, and then between discrete semes, it forces the interpreter to identify as precisely as possible what information a signifier means to convey. Once the relevant set of semes has been identified, an interpreter can test the semantic range of the signifier by creating oppositional signifiers corresponding to each of those semes, then asking test questions to determine the semantic boundary between that signifier and its opposites. In the example above, if it emerged that a back is a relevant aspect of A's /chair/, the signifier /stool/ would function as an oppositional signifier - the semantic equivalent of /not a chair/. B could then pose a series of test questions to define the precise boundary between the semantic range of /chair/ and /stool/; for example, whether a stool with a low back would be considered a /chair/ or a /stool/.

What this example further demonstrates is that the semantic boundaries of a given signifier can never be defined with complete precision. The distinction between /chair/ and /stool/is not simply the presence or absence of a back, since a low back would presumably not qualify something as a chair, just as a slightly-lower-than-normal back wouldn't disqualify it. Presumably there is some height at which the back renders a "something to sit on" a chair, but it would potentially require an infinite number of test questions to determine that height absolutely precisely. One could then repeat the same process with a host of other factors that might influence whether or not the back rendered the object a /chair/, such as its width, thickness, stability, shape, etc. In other words, /back/ itself becomes the subject of semantic analysis, and hence becomes vulnerable to what is known as the Sorites paradox, or the paradox of the 
heap: given that one grain of sand doesn't constitute a heap, and that no one grain added to something that's not a heap will make it a heap, it follows that no number of grains of sand will constitute a heap! Scholars often "solve" this paradox by acknowledging that some terms are inherently vague, but a semiotic model shows that any signifier is subject to this fundamental vagueness to a greater or lesser degree, the degree dependent only on the extent to which the context in which the signifier appears helps clarify its meaning; that is to say, there are no signifiers that are inherently vague any more than there are signifiers that have inherent meaning. Ultimately the functionality of semiotic systems relies on our being able to make clear distinctions between different signifiers, but as those distinctions get finer and finer, they will necessarily begin to seem arbitrary and absurd, ${ }^{7}$ just as it seems arbitrary and absurd to determine that the boundary between /not a heap/ and /heap/ should be drawn between, say, 242 and 243 grains. Because absolute semantic boundaries cannot be established, there can be no hard-and-fast rules for how a given signifier is to be used.

The simple model we have developed to describe the way individual words or phrases generate meaning may not seem relevant to much longer and more complex texts. However, any unitary text can be summarized according to the general meaning that a particular society attaches to it. Thus Othello might be referred to as "a tragedy of love and jealousy," and the book of Jonah may be called "a discourse on repentance." Obviously these works can be dissected much further by analyzing the significance of specific lines or passages in each, but if they are to function as units within a system of meaning (in this case, a literary or religious canon), one must be able to speak of their unitary, overall significance. If so, these texts too, despite their length and complexity, can be said to have one-to-one correspondence with specific ideas, and

7 The following passage from the Babylonian Talmud, Bava Batra (23b), illustrates this idea nicely:

Mishnah: If a young pigeon is found within fifty cubits [of a dovecote]-it belongs to the owner of the dovecote; [if it is found] beyond fifty cubits-it belongs to the finder....

R. Jeremiah inquired: If one foot is within fifty cubits and the other beyond fifty cubits, what is the ruling? It was for this that they expelled R. Jeremiah from the study hall. 
the relationship between each text and its corresponding meaning follows the same fundamental principle that Saussure laid down for much smaller text units, namely that the two are fundamentally distinct entities that associate with one another only contextually. This is precisely the power of a broad-based semiotic model: it establishes a universal set of principles for any form that communicates information.

This underlying identity of all sign systems has vital implications for hermeneutics in general. To put it plainly, semiotics rejects what we might refer to as a formalist position, that the meaning of a text is somehow fixed by the intent of the author, the historical context of its creation, etc. Rather, the meaning of a text is a function of the process of interpretation, and is circumscribed only insofar as the context of that interpretation is circumscribed (e.g., by what the literary scholar Stanley Fish refers to as an "interpretive community"). This position has been expressed, in one form or another, by numerous schools of literary criticism and legal scholarship over the past few decades. What a semiotic model contributes is a more rigorously methodological perspective on the issue, and with it a sense of conclusiveness: if Saussure's fundamental thesis is correct, then the formalist position is simply untenable. As much as literary or legal texts may seem to present their own meaning, at least in a general sense, they can be no more self-interpreting than any other signifier.

However, a semiotic model of law would also reject the most extreme version of anti-formalist legal theory, the position known as legal shamanism: legal terms are, like a shaman's incantations, fundamentally meaningless expressions that judges invoke to convince their audiences that they are doing something substantive. Rather, it shifts the focus from what legal rules cannot do-determine their own range of application-to what they can: communicate legal meaning in a contextdependent fashion - that is to say, tell people something (though never everything) about how the law expects them to act in a particular set of circumstances. This shift in emphasis allows us to articulate why inconsistencies in the application of legal concepts don't undermine the validity of law as a system-or more precisely, to articulate what we mean when we speak of law as a coherent system. Law coheres in the same sense that every other semiotic system coheres: it constitutes a network of signifiers and signifieds that associate with one another in a way that conveys information. In eschewing both of these extreme 
positions - that legal texts have either a single, straightforward meaning or no meaning at all-a semiotic model suggests a deeply intuitive approach to legal hermeneutics. This is the message we want to convey to students who struggle with Talmudic logic-that what seems like an arcane system of inferences, comparisons, and distinctions shares fundamental features with all other sign systems and can be approached using the same tools used to analyze those systems.

\section{Interpreting Legal Terms and Concepts}

A simple instance of how semiotic analysis can be applied to law comes to us in one of the basic notions in Anglo-American property law, the idea that ownership is comparable to a "bundle of sticks." What jurists mean by this is that ownership is not a uniform legal entity, but rather an assemblage of specific rights and responsibilities, the components of which can vary from case to case. Whether an individual is considered the owner of an object or property will therefore vary based on the context, depending on whether her particular "bundle" of rights and responsibilities includes the "stick" relevant to that context. For example, one may be considered the owner of a property when it comes to the right to exclude others from that property (considered one of the most basic rights to property) but be restricted in one's ability to transfer it to others (for instance, by a lien). Likewise, there can be discrepancies between the standards for ownership imposed by different jurisdictions even with reference to a single feature.

The metaphor of the bundle has thrived in legal circles largely because of the ease it affords jurists and lawyers when dissecting legal issues concerning property. Normally the notion that a bedrock legal concept such as ownership has no fixed definition would be immensely disconcerting. There is - let it be said-something deeply appealing about the sort of absolutist vision of legal hermeneutics according to which legal texts simply "mean what they say," if only because the (presumed) purpose of legal texts is to communicate law clearly and unambiguously. As a result, even those with no interest in the scholarly debate find themselves drawn toward the formalists' position. The simple, concrete image of the bundle anchors a concept that is both highly abstract and potentially destabilizing. 
The bundle image is, of course, merely another way of articulating the semiotic model of law that we have developed. The various rights and responsibilities related to property are the semes which, alone or in combination, constitute the sign-meaning of /ownership/. Just as the semantic range of a linguistic signifier such as /chair/ can be determined only by studying the specific attributes people use it to communicate (e.g., "something to sit on", "wooden object"), so, too, the semantic range of /ownership/ can be established only by knowing which specific rights and responsibilities the law applies to one considered an /owner/. But /ownership/ is merely one example; any legal signifier is comparable to a "bundle of sticks," its definition wholly dependent on the specific contexts in which it is applied.

As we turn to examples of statutory interpretation of mishnayot, let us first examine instances where the indeterminacy of the text centers on a single term. Consider Mishnah Kiddushin 3:5:

[If a man states:] "I betrothed my daughter, but I don't know to whom I betrothed her," and another individual comes and states, "I betrothed her" - he is believed....

What does the mishnah mean when it rules that this individual is /believed/? When I ask my students to paraphrase the mishnah's ruling, they usually see no basis for ambiguity: it means simply that we accept his words as truth. Certainly nothing in the mishnah prepares them for the amoraic debate that follows:

Rav stated: He is believed in order to give her a get, but he is not believed in order to marry her.... R. Assi stated: He is believed even in order to marry her.... (B. Kiddushin [63a])

Based on my students' instinctive reading of the mishnah, $\mathrm{R}$. Assi's position emerges naturally from the mishnah text while Rav's distinction seems groundless. Simply put, if we accept this man's selfidentification as the betrother (i.e., the one who already completed the legal act of kiddushin, the first stage of the legal act of marriage), why would we forbid him to "marry her" - that is, to proceed with the act of nissuin (the domestic and sexual consummation of marriage)? Once again, the formalist impulse-the reflexive search for a single, 
unequivocal meaning - shapes the way students process the mishnah's language. In this case, that impulse makes it difficult for them to understand the dynamics of a debate when one side seems to violate that unified meaning.

A semiotic model can help students understand how multiple meanings can be constructed from an apparently straightforward text. Once we understand that all signifiers are equally indeterminate, we realize that the meaning of /believed/—no less than /ownership/ or /chair/is context dependent. Without articulating with regard to what this individual is believed - that is to say, what the practical ramifications of believing him will be-the mishnah's ruling has no meaning in a legal sense. Any interpretation must, therefore, begin with an assessmentconscious or unconscious - of the purpose for believing this would-be husband. If R. Assi's interpretation seems the simpler of the two, that may be because we take for granted that betrothal naturally concludes in marriage, and that the purpose of believing this individual is to allow the betrothal to follow its natural course. But sometimes chairs need to be used for fuel rather than furniture, and marriages need to be dissolved rather than consummated, and so Rav contends that the mishnah is interested in identifying the mystery suitor only because he holds the key to freeing the daughter from her status as an agunah-a woman inexorably "bound" to a marriage and consequently unable to marry another.

A similar analysis could be applied to the term /betrothed/ in Mishnah Kiddushin 3:1:

[If a man] says to his friend, "Go betroth such-and-such woman for me," and [his friend] went and betrothed her for himself-she is betrothed to the second; and so, too, [if a man] says to a woman, "Behold, you are betrothed to me after thirty days," and another came and betrothed her during the thirty days - she is betrothed to the second: [if she is] the daughter if a non-priest [marrying] a priest, she may eat terumah.

[However, if a man says, "You are betrothed to me] from today and after thirty days," and another came and betrothed her during the thirty days-she is betrothed and not betrothed: [if she is] the daughter of a non-priest [marrying] a priest or the daughter of a priest [marrying] a non-priest, she may not eat terumah. 
The first time I taught this mishnah, I was surprised to find that the aspect my students found most puzzling was the repeated allusion to the woman's status vis-à-vis the consumption of terumah. Those with experience studying Talmud take this sort of "status marker" for granted, and the ability to eat terumah is a common marker in cases involving priestly status. But to the uninitiated student, the issue of terumah consumption seems to have little relevance for the issue at hand.

Rather than dismiss the reference as a common rhetorical device, I used a semiotic approach to address why the author of the mishnah would feel a need to use this status marker. From a semiotic perspective, these allusions function as interpretants that clarify the mishnah's ruling-/betrothed/ or /betrothed and not betrothed/. But an interpretant seems utterly extraneous in the context of the first set of cases, where, like /believed/ in the previous example, /betrothed/ appears to be self-defining: the reader implicitly understands the ramifications of the woman's status as "betrothed", including its impact on her ability to eat terumah. In order to explain how /betrothed/ is not self-defining, I employed the "bundle of sticks" metaphor, explicitly drawing a parallel between the legal concepts of betrothal and ownership.

Like ownership, betrothal can be reduced to an assemblage of legal rights and responsibilities (as well as non-legal aspects, of course, such as love or fidelity), so that ultimately its legal import can be measured only in terms of its specific practical ramifications. And just as the sticks in the ownership bundle can be "unbundled" to correlate with the many different permutations of ownership, so, too, the various rights and responsibilities of marriage can combine in different ways, so that not every instance of betrothal will have exactly the same set of legal ramifications. We could ask for no better illustration of this than the mishnah's ruling in the second set of cases, where /betrothed/ is bizarrely paired with its polar opposite-/not betrothed/. In truth, the construct " $\mathrm{X}$ and not $\mathrm{X}$ " is not as strange as it at first sounds. Similar phrases appear elsewhere in rabbinic literature with the sense of "partially X," ${ }^{8}$ and parallels exist even in modern parlance (English speakers understand exactly what is meant by the response "yes and no"). In this instance, this construct denotes the inconclusive nature of the betrothal, what

8 For example, bashel ve'lo bashel (lit., "cooked and not cooked") is used in Sabbath (18b) in the Babylonian Talmud to mean "partially cooked." 
the Mishnah elsewhere (Yebamot 3:8) refers to as kiddushei safek (lit., "dubious betrothal"). But in terms of expressing the nature of this woman's legal status, /betrothed and not betrothed/ is exactly correct: because the betrothal is inconclusive, she is neither fully "betrothed" nor fully "not betrothed"; rather, her status combines aspects of both.

This synthesis requires explanation, however, and so the mishnah invokes an interpretant-/bat yisrael le'kohein o bat kohein le'yisrael lo tokhal bi'terumah/— to explain that her status combines only the restrictive elements of each: she is "betrothed" as far as losing her right to eat terumah if marrying out of a priestly family, and also "not betrothed" as far as not gaining such a right if marrying into a priestly family. The combination of two terms that are normally mutually exclusive demonstrates the inherent instability of each; that is to say, it demonstrates that no term necessarily signifies the full set of semes normally associated with it. Based on this, we can better understand what the interpretant /bat yisrael le'kohein tokhal bi'terumah/ adds to our understanding of /betrothed/ in the first half of the mishnah: despite the involvement of the first suitor, there is no lingering doubt about the woman's betrothal to the second. She is "betrothed" in the full normative sense of the term.

\section{Interpreting Composite Legal Texts}

The sort of analysis engendered by /betrothed and not betrothed/ brings us to the next stage of our study: the analysis of composite legal signifiers - that is, legal texts longer than a single word or phrase. Fundamentally, semiotic analysis of composite signifiers involves the same basic principles we outlined regarding the analysis of simple signifiers. First, the interpreter must deconstruct the sign-meaning into its potential component semes, though now those semes are themselves signifiers - individual terms and phrases-whose semantic range must be established in order to understand the meaning of the text as a whole. Then the interpreter must decide the relative importance of those semes within the text's overall meaning, including-as will invariably be the case-those which aren't relevant at all.

This hermeneutic approach obviously shares much with poststructuralist literary theory. Literary scholars such as Roland Barthes 
and Jacques Derrida demonstrate the ways in which texts are necessarily fragmentary, and then use this idea to destabilize the meaning of the text and to demonstrate that no interpretation can claim singular authority. The point of drawing on post-structuralism, however, is not to adopt a nihilistic position on legal hermeneutics, whereby the indeterminacy of legal texts undermines their ability to dictate law. Unlike literary critics, jurists do not have the luxury of merely pondering the open-endedness of meaning. The role of the jurist is to bring clarity and consistency to the workings of the legal code. As such, her interpretation-singular or not-must be regarded as authoritative in order for the system to function. What an appreciation of indeterminacy yields, however, is an understanding of the process of interpretation, and-as with simple legal signifiers - a more accurate account of what happens when jurists disagree about the meaning of a legal text.

In introducing my students to this form of analysis, I have found it extremely beneficial to begin with the following example from contemporary law, which they find familiar and accessible. One of the most contentious hermeneutic issues in contemporary American law is the interpretation of the Second Amendment to the Constitution: "A well regulated Militia, being necessary to the security of a free State, the right of the people to keep and bear Arms, shall not be infringed." On one level, the debate over what this text signifies revolves around the meaning of the individual terms within it. What constitutes /infringement/? What is meant by /keep and bear/, and should they be understood as two separate terms or as a single phrase? For the most part, each of these terms can be defined-and thereby shape the meaning of the overall text-independently from one another. On another level, however, the debate concerns how to resolve the contradictory implications of these terms with one another. For instance, the preamble's reference to a /Militia/ seems to limit the semantic range of the text to militia-related arms, but the subsequent reference to /the people/ seems to broaden its scope to arms possessed by individual citizens. Since in their fullest form these implications are mutually exclusive, neither term's meaning can be assessed without considering its impact on the other's.

Once the conflict between these terms has been established, there is no unwritten rule that an interpreter must find the compromise meaning 
that best balances the implications of both terms. ${ }^{9}$ At this second level of analysis, the question is not merely what each of these terms means, but to what extent that meaning functionally impacts the semantic range of the law-indeed, whether it affects it at all. If a jurist is convinced that "the people" necessarily encompasses all citizens, irrespective of their participation in the militia, then the reference to /Militia/ (and with it the entire preamble) has little or no impact on how she would apply the law. The same is true of the phrase /the people/ for a jurist who understands "Militia" as referring exclusively to a formal military body. ${ }^{10}$ Hermeneutic purists will surely object to interpreting such a carefully

9 Ronald Dworkin famously makes the case that the task of legal interpretation is to do precisely this - to construct the "best" possible meaning of the law.

10 Adam Freeman's analysis of the current debate over the implications of the commas (!) in the Second Amendment ("Clause and Effect," New York Times OpEd page, Dec. 16, 2007) is a case in point:

The decision invalidating [Washington, DC]'s gun ban, written by Judge Laurence H. Silberman of the United States Court of Appeals for the District of Columbia Circuit, cites the second comma (the one after "state") as proof that the Second Amendment does not merely protect the "collective" right of states to maintain their militias, but endows each citizen with an "individual" right to carry a gun, regardless of membership in the local militia.

How does a mere comma do that? According to the court, the second comma divides the amendment into two clauses: one "prefatory" and the other "operative." On this reading, the bit about a well-regulated militia is just preliminary throat clearing; the framers don't really get down to business until they start talking about "the right of the people ... shall not be infringed."

The circuit court's opinion is only the latest volley in a long-simmering comma war. In a 2001 Fifth Circuit case, a group of anti-gun academics submitted an amicus curiae (friend of the court) brief arguing that the "unusual" commas of the Second Amendment support the collective rights interpretation. According to these amici, the founders' use of commas reveals that what they really meant to say was "a well-regulated militia ... shall not be infringed."

Now that the issue is heading to the Supreme Court, the pro-gun American Civil Rights Union is firing back with its own punctuation-packing brief. Nelson Lund, a professor of law at George Mason University, argues that everything before the second comma is an "absolute phrase" and, therefore, does not modify anything in the main clause. Professor Lund states that the Second Amendment "has exactly the same meaning that it would have if the preamble had been omitted." 
worded document (the final draft of the Second Amendment-like virtually all constitutional texts - was the product of lengthy and heated debate) without taking every word and phrase into account. After all, doesn't the text of the law explicitly mention both /Militia/ and /the people/? But the fact that the text functions as a semiotic unit- the fact that the law can mean only one thing within a given context-says that its overall meaning is fundamentally indeterminate and isn't limited by the sum of its parts. This is not to say that the conflicting implications are irrelevant to one's understanding of the text. Quite the opposite: a jurist will necessarily have confronted the internal tension in the text before deciding what it means. But having completed that analysis to her own satisfaction-having decided on the subset of semes that will determine the semantic range of the text-the jurist can now conceive of that text as expressing a single concept: "what the Second Amendment means." Those semes that conflict with the jurist's interpretation cease to have any legal significance for her.

Given these inevitable textual sacrifices, ${ }^{11}$ however, not to mention the highly politicized nature of this debate, one could be excused for suggesting that all this hermeneutic analysis is beside the point. It often seems as though the legal positions have nothing to do with interpretation at all, the textual arguments being no more than windowdressing for distinctly non-legal considerations. Such ruminations are characteristic of contemporary legal theorists who take a thoroughly agnostic view of judicial interpretation. But again, denying that a text determines its own meaning is different than denying that a text means anything at all. The very fact that textual arguments can be articulated at all means that the words carry some weight in the way we make sense of the Amendment as a whole. If it still seems that both of the above interpretations violate the simple sense of the text-or to put it differently, if the text doesn't seem to generate any obvious meaning that is relevant to the current debate-that may be because the context in which the Second Amendment was drafted was significantly different than our own. In an era when state militia were composed of ordinary citizens who provided their own weapons, /Militia/ and /the people/ posed fewer conflicting

11 That is, the need to reject some inferences that could be made from the text, essentially declaring that certain aspects or portions of the text are irrelevant to the meaning of the text as a whole. 
implications. But the binding nature of law means that the Amendment must still be made relevant even though times have changed, forcing jurists into the awkward position of having to decide which of these terms reflects the "real" scope of the law.

Using this model, we can analyze a more complex instance of Talmudic interpretation than those cited above. Mishnah Kiddushin 3:7 states:

[If a man] has two groups of daughters by two wives and says, "I married off my elder daughter, and I don't know whether [the betrothal referred to] the elder daughter of the seniors, or the elder daughter of the juniors, or the younger daughter of the elders who is older than the elder daughter of the juniors"- they are all prohibited [to marry another] except the younger daughter of the juniors; this is R. Meir's position. R. Yose says: They are all permitted [to marry another] except the elder daughter of the seniors.

The mishnah presents a highly unusual case in a somewhat unusual fashion. Normally mishnayot include only two components-a concise explanation of the case(s) or issue(s) at hand, and an even shorter record of the ruling (or the debate over the ruling) associated therewith. In this mishnah, however, the brief introduction that sets up the background of the case is followed by a relatively lengthy record of the father's thought process, which not only introduces the complicating factor in the case (he can't recall which daughter he intended to betroth) but also explains the rationale for implicating multiple daughters as the one who was betrothed (any of them might conceivably be referred to as "elder"). The Mishnah then presents R. Meir and R. Yose's rulings in typically succinct fashion, with no account of their reasoning or how it might relate to the logic of the father's internal monologue.

Its peculiar style notwithstanding, the mishnah reads fairly coherently. A cursory reading gives no evidence of the tension that emerges in the Talmud (Babylonian Talmud, Kiddushin 64b-65a), as the amoraim investigate the parameters of the tannaitic debate:

Abaye said: The controversy refers [only] to two groups of daughters; but in the case of one group, all agree that "elder" [refers to the eldest daughter], "younger" [refers to the youngest daughter], and the middle daughter is referred to as such. 
R. Ada b. Matna said to Abaye: If so, the middle daughter of the [junior] group [within a family with two groups of daughters] should be permitted [according to all]!12

What case are we dealing with here? Where there are only [two daughters in the junior group], ${ }^{13}$ and this is a logical [assumption], for if there is a middle daughter [in the mishnah's case], let her be mentioned!

But even in your view, the middle one of the first [senior] group, who is certainly [implicated in the ambiguous betrothal] and forbidden $^{14}$ - is she mentioned ? $^{15}$

How can you compare? [Regarding the middle daughter of the senior group, even] the one younger than her is mentioned as being forbidden, and the same applies to this [middle] one, who is older than her; but [regarding the junior group], if it is so that there is [a middle one], let her be mentioned!

Abaye states that R. Meir's stringent position-that all but the youngest daughter must receive a get before marrying another-applies only to a case where the father has two groups of daughters from two wives. However, in a case where all the daughters are from a single wife, the ambiguity that triggers R. Meir's stringency disappears: Abaye insists that in such a family, the middle daughter would be referred to by her exact sibling position, and therefore wouldn't be implicated in the father's betrothal of his "elder daughter." R. Ada bar Matna challenges Abaye's position regarding the middle daughter by drawing a comparison to (what he assumes is) a known quantity: the

12 She, too, should be referred to simply as the "middle daughter," since she has no more seniority than the middle daughter in a family with only one group of daughters; both are older only than the youngest daughter in their family. Clearly R. Ada bar Matna assumes that R. Meir would prohibit the middle daughter of the junior group, thereby contradicting Abaye's understanding of his position.

13 Therefore the mishnah tells us nothing about R. Meir's position regarding the middle daughter of the junior group, and it's possible that even R. Meir would permit her to marry without first receiving a get.

14 As explained in the next line: The middle daughter of the senior group is obviously forbidden, since she is older than the youngest daughter of the senior group, who is herself explicitly implicated.

15 So the fact that a given daughter isn't explicitly mentioned doesn't mean that her status is uncertain. 
status of the middle daughter within the younger of the two groups of daughters. If R. Meir would implicate this daughter as possibly being the betrothed "elder daughter" even though she has only one younger sister, then surely he would say the same regarding the middle daughter of a single group, even though she, too, has only one younger sister. The Talmud then debates what evidence the mishnah provides regarding the middle daughter of the junior group, and whether it supports R. Ada bar Matna's assumption that R. Meir would prohibit her. In the process, the Talmud weighs the possibility that the case addressed in the mishnah has no middle daughters at all, but rather two groups of only two daughters each.

This is a short but difficult passage. With each new daughter who is introduced to the discussion and each minute shift in the understanding of R. Meir's position, the reader is forced to double back and reexamine her previous assumptions. It can be helpful, even at the initial stages of negotiating the Talmud's give-and-take, for students to see how the positions of the amoraim positions are-at least implicitlygrounded in inferences from the mishnah text. This allows students to link each stage of the argument to a line in the mishnah, transforming what might have been seen as an abstruse conceptual debate into a more concrete interpretive one. For instance, Abaye may defend his distinction between one group of daughters and two groups of daughters on logical rather than textual grounds ("... the middle daughter is referred to as such"), but it's clear that what enables his interpretation is the mishnah's reference to a man who "has two groups of daughters from two wives," implying that a similar case involving a man with only one group of daughters wouldn't evoke the same tannaitic debate. Similarly, R. Ada bar Matna's rejoinder-"If so, the middle daughter of the second [junior] group should be permitted [according to all]!"makes no sense without textual evidence that R. Meir would, in fact, prohibit the middle daughter of the junior group, something implied only by the wording of his ruling, "They are all prohibited." Finally, the Talmud defends Abaye's position by explicitly citing the fact that no middle daughter is mentioned in the father's speech. Though on one level this analysis is simply to help the students grasp the various amoraim's positions, by the end I have succeeded in making a more subtle hermeneutic point - that the amoraic debate reflects the tension inherent within the mishnah text itself. 
Nonetheless, even once they have mastered the intricacies of the debate, students often harbor a sense of discomfort about the Talmud's excessive scrutiny to textual detail. It may be granted that each of the amoraim's positions can be linked to an inference in the mishnah text, but aren't these inferences rather strained? There is a hint of anti-formalist sentiment at work here, a sense that judicial interpretation is detached from the text of the law. This sentiment is usually so subconscious that it goes unexpressed. When students do articulate it, a teacher's reaction is often simply to invoke the peculiar nature of the rabbinic hermeneutics: like midrashic exegesis of the Bible, which extracts the maximum possible meaning from every word, the Talmud reads the Mishnah text with the assumption that it is articulated in highly deliberate fashion. From a purely pedagogic standpoint, this is a less-than-ideal response, for the simple reason that it asks the student to suspend his critical faculties, thereby reinforcing his sense of distance from the text. But it is also not altogether accurate, for the assumption that texts are articulated in highly deliberate fashion-far from being particular to rabbinic hermeneutics - is intrinsic to virtually all legal systems. The gravity of law demands that it be so: in everyday conversation it may not matter whether an object falls within the semantic range of /chair/, but in a legal context, such determinations - for example, whether private ownership of a handgun is covered by the Second Amendment-can have significant and wide-ranging consequences. In considering whether the mishnah's ruling does or doesn't apply to a particular case and does or doesn't restrict the marriageability of a particular daughter, the amoraim are merely exploring its precise semantic parameters, defining "what Mishnah Kiddushin 3:7 means," as they would need to do with any legal pronouncement.

The debate over Mishnah Kiddushin 3:7 illustrates particularly clearly the way interpretation becomes an act of reading a text against itself, as jurists are forced to choose between the conflicting implications that emerge from the text, sometimes from a single word. A simple exercise I have used in teaching this mishnah is to ask students to consider the implications of the opening line- "[If a man] has two groups of daughters by two wives...." A straightforward reading would suggest that, a) the mishnah's ruling would apply to all families with two groups of daughters (otherwise wouldn't it mention the exceptional cases?), but also, b) that the mishnah's ruling wouldn't apply to any families with 
only one group of daughters (otherwise why mention specifically "two groups"?). Now I ask the students to consider how these inferences stand up to the Talmud's analysis. Abaye clearly articulates the second inference, but then R. Ada bar Matna uses the first inference to challenge him: since there is no logical distinction to be made between the middle daughter of a single group of daughters and the middle daughter of the junior of two groups of daughters (each is next-to-youngest in her family), Abaye's exclusion of all one-group families would also end up excluding some two-group families, something not indicated by the mishnah's language. What the amoraic debate demonstrates, then, is that these two inferences-each perfectly reasonable on its own-are mutually exclusive. Abaye and R. Ada bar Matna each define the meaning of the mishnah in concert with one of these inferences, thereby excluding the other from having legal significance.

\section{Understanding Legal Evolution}

As we mentioned above, a semiotic model of law can also be used to help students understand the way law develops over time. This is helpful when approaching a text such as Mishnah Avodah Zarah 5:2, which is formulated in a way that suggests something about its composition history:

If [idolatrous] libation wine fell on grapes, one should rinse them and they are permitted, but if they were split [when the wine fell on them], they are prohibited..$^{16}$ If [libation wine] fell on figs or dates, if there is [sufficient wine] in them to impart flavor, it is prohibited.

There was an incident involving Boethus ben Zunin that he brought dried figs on a ship, and a cask of libation wine broke and fell on them, and he consulted the Sages who permitted them.

This is the general principle: Whatever benefits [from the libation wine's] imparting a flavor [to it] is prohibited, but whatever doesn't benefit [from the libation wine's] imparting a flavor [to it] is permitted, such as vinegar that fell upon split beans.

16 The Talmud (Babylonian Talmud, Avodah Zarah 66a) debates whether this applies regardless of the ratio of wine to grapes, or only if there was sufficient wine to impart taste to the grapes (as is the case with dates and figs). Our analysis, however, will address only the law regarding figs and dates. 
The mishnah progresses in four distinct stages: 1) the initial case-specific rulings regarding libation wine that fell on grapes, dates, or figs; 2) the case involving Boethus ben Zunin's dried figs, which the Sages permit for unspecified reasons; 3 ) the general distinction between foods that benefit from the flavor of the wine and foods affected adversely by its flavor; 4) application of this principle to the case of vinegar (presumably made from libation wine) that falls into a dish of split beans. While the mishnah doesn't articulate the connection between the stages, their sequence suggests that the historical event is what precipitated the general formulation of the law: the conceptual distinction between complementary and uncomplementary flavors seems to have been tacked on to the earlier part of the mishnah in order to resolve the Sages' lenient ruling in the Boethus ben Zunin incident with the existing law. ${ }^{17}$

If this assessment is correct, we can use the model we developed above to analyze the diachronic shift in the law's perceived semantic range. Before the conceptual formulation, the semantic range of the law was defined only by /figs or dates/; there was no basis for determining what the relevant semes of /figs and dates/ should be, and therefore no additional guidance for determining the semantic range of the law. Here, then, is an opening to stretch students' interpretive skills: what principle might we have formulated from this specific case had one not already been provided for us? Should it apply to all foods? Only sweet foods? Only raw foods? Only fruit? At the very least, students will typically insist - based on an intuitively formalist reading of the text-that the law applies to all /figs and dates/, regardless of whether they are fresh or dried. For the rabbis, however, the relevant seme of /figs and dates/ is none of the above, but rather that the wine complements their flavor. /Whatever benefits [from the libation wine's] imparting a flavor [to it]/ serves as an interpretant for /figs and dates/, the same way /something to sit on/ serves as an interpretant for /chair/. As counterintuitive as it may seem, /dried figs/ now becomes an oppositional signifier to /figs/, since only fresh figs fall within the semantic range of

17 Text-critical scholars have long noted the frequency of mishnayot that exhibit this basic pattern-a list of specific cases followed by a zeh ha-k'lal ("this is the principle") clause, and suggest that even when the ontological or chronological development isn't as blatant as in this case, this form points to the diachronic development of the Mishnah text. 
the interpretant. ${ }^{18}$ But students will appreciate the significance of this interpretive move much more if they have spent time formulating their own general principle before considering that of the rabbis.

At this point the students' instinct may shift to an anti-formalist perspective: isn't the sages' ruling merely a ruse to save Boethus ben Zunin's figs, and not a justifiable interpretation of the original law? Without additional information about the event, we have no way to assess the sages' motives, but there's no reason to assume that wanting to save Boethus ben Zunin's figs did not play a role in their decision. What I want to convey to my students is that while we can question the wisdom of a judicial system that allows such factors to influence legal rulings, a semiotic model shows that partiality per se doesn't invalidate an interpretation. Even the most neutral reading of the law has to emphasize some semes at the expense of others, and a corollary of the fact that signifiers aren't self-defining is that all semes have equal potential to determine a signifier's semantic range. The validity of this process of picking and choosing semes is established by its very necessity: a functioning semiotic system depends on the ability of its users (both speakers and listeners) to assign meaning to signifiers as they see fit, regardless of the generally perceived prominence of the semes they choose to ignore.

18 In presenting this sugya in translation, I have chosen to simplify the analysis somewhat. When I presented this paper at the Mandel Center Conference on Teaching Rabbinic Literature, Lawrence Kaplan noted that the mishnaic Hebrew term for dried figs is grogerot, not te'einim, so that the rabbis' lenient ruling in the Boethus ben Zunin case may not have been perceived as conflicting with the existing law regarding figs (just as English speakers might not consider a reference to /plums/ as also referring to prunes). Nonetheless, I maintain that the mishnah's deliberate juxtaposition of the rabbis' ruling with the original law shows that the author of the mishnah did perceive a conflict between them.

However, even if the rabbis' ruling doesn't directly conflict with the dictum regarding figs and dates, it still marks a major break with the general principle-stated several times in the Mishnah and clearly operating here-that kol she'yeish bahem benotein ta'am asur (a forbidden substance that imparts taste to permitted foods renders those foods forbidden). Against the background of this principle, the rabbis' permitting of Boethus ben Zunin's figs is clearly highly innovative. Indeed, the principle of notein ta'am lifgam, mutar (if the taste that is imparted is a spoiled taste, then it is permitted) eventually becomes a major exception to the general principle of kol she'yeish bahem benotein ta'am asur. 


\section{Conclusion}

The methodology I have presented here represents only one of many possible perspectives on talmudic reasoning, one that emphasizes the similarities between Talmudic law and other legal systems. In doing so, it implicitly downplays the many distinctive features of talmudic law, as well as the differences between religious and secular legal systems, all of which are important to a well-rounded understanding of how the Talmud and halakha function. However, given that students tend to already appreciate the distinctiveness of Talmudic and halakhic reasoning and distinguish between all things secular and religious, I feel that it is important to underscore the basic elements that all legal systems share. More fundamentally, a semiotic model does more than draw parallels between different legal systems; it speaks to the very essence of hermeneutics. When we give our students the tools to analyze how text generates meaning, every aspect of Talmud and halakha-both the generic and the idiosyncratic - becomes more comprehensible. 